\title{
READINESS LECTURER FACULTY OF LAW IN THE ERA COMPETITION ECONOMIC COMMUNITY ASEAN
}

\author{
Halimatul Maryani \\ Faculty of Law, Universitas Muslim Nusantara Al Washliyah Medan \\ maryaniritonga@yahoo.co.id
}

\begin{abstract}
The background of this article is written that Indonesia and Southeast Asian countries are already within the scope of the Asean Community. So each country must prepare human resources (HR) lecturers in the competition of the labor market in the Southeast Asian region. Given the increasingly fierce competition, of course it requires the expertise of a workforce (lecturers) who are ready to be competitive, of courseIn this era of globalization of international competition. The purpose of this study was to examine the role and readiness of lecturers in competition in the era of the international economic community, with the method used in this research is the normative juridical method and its use to encourage lecturers to be more active in implementing the Tri Dharma of Higher Education. As aconclusion, lecturers are obliged to carry out the tri dharma of higher education and play a very important role in the development of higher education institutions, especially the respective universities they do and each lecturer is advised to apply the results of their performance in the lecture material.
\end{abstract}

Keywords: Readiness, Lecturer, International Competition, MEA.

Journal History

Received : March 08, 2021;

Reviewed : March 25, 2021;

Accepted : April 07, 2021;

Published : April 14, 2021.

\section{INTRODUCTION}

The Association of Southeast Asian Nation or commonly known as ASEAN has become part of the international system which raises many things such as challenges, obstacles, opportunities, hopes and roles in the journey of this Asean region organization and becomes a conical problem so that there is a desire to integrate. The latest issue on the globalization scale of international competition is the emergence of the issue of the Asean Economic Community (MEA) or "Asean Economic Community (AEC) " and there are still many people who do not understand this, it is predicted that it will be a challenge for Indonesia, because mass stuttering will emerge. especially for the untrained and untrained workforce as Human 
Resources, including lecturers. The question arises, can our lecturers and education compete in the MEA circle? How do the lecturers respond? Do the lecturers just give up without preparation?

Talking about the role of lecturers as well as being a challenge for lecturers, whose scope is the academic community, it is certain that it includes lecturers, meaning that in globalization there are new challenges for the world of science and universities. The people in charge of academic institutions, especially lecturers, are very instrumental in adjusting the higher education system in Indonesia with new demands that will apply internationally. The performance of lecturers plays an important role in strengthening higher education institutions in the era of the Asean Economic Community, because lecturers are one of the spearheads and important assets in improving the quality and quality of higher education, for example how their roles are as figures, role models, leaders, core officials, functionaries, lecturers and so on.

Looking at this, as a real comparison based on the analysis, experience and research that has been experienced before the emergence of the issue of the Asean Economic Community (AEC), is ready to be unprepared, whether you want it or not, and like it or not, willingly or not, at this time Indonesia is already entered and has been the implementation of AFTA-China I ASEAN-China Free Trade Agreement yang shortened by the ACFTA since 2004 ago. As a result and the impact after the AFTA-China agreement in Indonesia in general, especially the provinces including North Sumatra were flooded with products from China whose prices were much cheaper than local products.

Likewise with the international competition of the Asean Economic Community, all must be ready to compete in all fields, including education, especially higher education. All elements related to higher education, one of which is lecturers, how lecturers play a role in responding to the international competition of the Asean Economic Community.

The existence of the AEC will make ASEAN a region that is fully integrated with the global economy, while the global economy is currently being directed towards a form of free market. In this free market, everyone is free to compete, so that small companies must be able to compete with large companies. Likewise, lecturers as the important spearhead of higher education institutions and students' reflection on the role of lecturers are expected to build and improve the quality and quality of education. Hence the title of this article is $\mathrm{K}$ esiapan Lecturer in the 
Faculty of Law d i Era of Competition of the Asean Economic Community (AEC).

Similarly, the international universities of the Asean Economic Community are all ready in all fields, including the field of higher education education. All elements that are intertpersed with higher education are wrongly misplaced lecturers, the way the lecturers in the sub-district in the international berkingkut Asean Economic Community.

The existence of MEA will be a region full of global economies, while the global economy is currently heading towards a free market. In this free market, everyone is free to carry on, so that small companies can be opposed to large companies. Also on the lecturer spear spear important college and reflection of the role of students the role of lecturers are very hopeful to build and improve the quality and quality education. Therefore, the title of this article is the readiness of Lecturers of the Faculty of Law in the Era of the Asean Economic Community Association (MEA).

\section{METHOD}

The method used in this research is more focused on juridical normative research ${ }^{1}$ in which the study was conducted with a focus on reviewing the application of the rules or norms of positive law related to the

1 Peter Mahmud Marzuki, Penelitian Hukum, (Jakarta:Kencana, 2005), p. 35. rule of law (Law U ndang ) and remain connected with juridical methods e mpiris , by nature penelitian is descriptive $^{2}$ in this case the writer tries to analyze and describe systematically. Sources of data in the study of legal documents / materials used to analyze legal issues in this research problem are primary legal materials, secondary legal materials, and tertiary legal materials. ${ }^{3}$ Where these three legal materials are the main data or are called secondary data, which includes:

Primary legal material, This material is p eraturan and statutory provisions as such written law, the constitution of the Republic of Indonesia Year 1945, Law No. 20 of 2003 concerning the National Education System, Law no. 14 of 2005 concerning Teachers and Lecturers.

Secondary legal materials, This secondary legal material is material that provides an explanation of primary law such as textbooks, research reports, scientific journals, magazines, newspapers, internet sites, and documents related to legal issues in this research.

Tertiary legal material, This is a supporting legal material that

\begin{tabular}{lcc}
\hline 2 & Johnny Ibrahim, & Teori \& \\
Metodologi & Penelitian Hukum & Normatif, \\
(Malang: Bayumedia, 2005), p. 46. & \\
342. Peter Mahmud Marzuki, Op. Cit, p.
\end{tabular}


provides instructions and explanations for primary and secondary legal materials, such as general dictionaries, legal dictionaries, Indonesian dictionaries, economic dictionaries.

While the data analysis used is basically the analysis of data / legal materials that has been carried out since the beginning of the research process using library research to field research. So that from the beginning, every legal data / material and information can be clarified. So all legal materials that have been obtained and collected, in the form of primary legal materials, secondary legal materials, and tertiary legal materials, are analyzed qualitatively. Legal materials that have been acquired are arranged systematically, so that it will produce a particular classification in accordance with pe formulation of the issues discussed in this study, then do the edit ing $d$ ith mengkelompokkan materials or materials in accordance with the chapters that have been determined in this study, and then draw conclusions using logic thinking and analyzing from deductive to inductive. ${ }^{4}$

\section{DISCUSSION}

\section{Definition of International Competition}

4 Bambang Sunggono, Metode penelitian hukum (Suatu Pengantar), (Jakarta: PT. RajaGrafindo Persada, 2001), p. 114.
Competition is a social process that involves individuals or groups competing with each other and doing something to achieve certain victories. Competition can occur when several parties want something limited or something that becomes the center of public attention. Competition takes place without threats or violence. May do persai ngan all fields, but the competition is a healthy competition and fair with memat Uhi certain rules, so that competition is healthy will have a positive effect for the parties competing, y aitu their motivation for the better. However, if the competition is no longer healthy, then the competition will have a bad impact on both parties. ${ }^{5}$

Furthermore, the definition of international is synonymous with cooperative relations bilaterally, regionally and multilaterally. Generally hu of flower internationally is cooperation between countries, namely units politics defined globally for solving various problems. According to Law no. 37 of 1999, international relations are activities regarding regional and international aspects undertaken by the government both at the central and i nternational such as central and local governments, state agencies, enterprises, political organizations, NGOs or

http://temukanpengertian.blogspot.com, diakses pada tanggal 6 Agustus 2015 
citizen. Another thing hu of flower international is a cooperation between countries, namely units politics defined globally for solving various problems.

When viewed from the aspect of international law in general, there are also three international relations, namely bilateral relations, regional and multilateral relations. International relations are considered important in the context of fostering mutual understanding between nations, strengthening friendship and brotherhood between nations, mutually providing for the needs of each nation that cooperate, fulfilling a sense of justice and prosperity, and fostering and upholding world peace and order. A country that does not want to establish international relations with other countries will be isolated in world relations. As a result, the country will experience difficulties in fulfilling their daily needs, in the end it will become an obstacle as well as a challenge.

The challenges and obstacles of the Indonesian nation in the future are increasingly complex and multidimensional. In 2015 , the Indonesian nation has entered the era of the ASEAN Economic Community (AEC). With the enactment of the AEC, people in ASEAN can conduct trade transactions both goods and services freely. This situation will require the Indonesian nation to have strong competitiveness.
The main concept of the ASEAN Economic Community is to create ASEAN as a single market and a unified production base where there is free flow of goods, services, production factors, investment and capital as well as the elimination of tariffs for trade between ASEAN countries which are then expected to reduce poverty and economic disparities between member countries through a number of mutually beneficial cooperation. The presence of the ASEAN Economic Community can help the helplessness of ASEAN countries in the global competition of the world economy by forming a single market based in the Southeast Asia region. Liberalization in the service sector that involves human resources may appear obvious because it concerns the placement of skilled and unskilled personnel to support the country's economy. However, the most influential and focused in the ASEAN Economic Community is a workforce that is skilled.

\section{Analysis Regarding the provisions of the Asean Economic Community}

Solly Lubis in Hadita (2020) The theory of power, Laski argues, along with Marx, namely that every association of life requires coercive instruments, thus claiming the continuation of a permanent production relationship, because if it 
were not so then the association of life would not be able to claim its livelihood. By Plato in his book "Politeia" Thrasymachos statement noted, that justice is the interest of the powerful who demanded the arrangement to the power that is there, it means that the law and the interests of the ruling is one. ${ }^{6}$

If we reopen the history sheet for the formation of Asean, geopolitically and geo-economically, the Southeast Asia region has a very strategic value in advancing regional economic cooperation (region $){ }^{7}$ and internationally, with clear objectives. The objectives of establishing ASEAN are: ${ }^{8}$

1. Accelerating economic growth, social progress and cultural development in the region through joint efforts in the spirit of equality and friendship to strengthen the foundation of a society of the

\footnotetext{
Cynthia Hadita, Regional Autonomy Political Politics Of Regional Liability Reports To Regional Representatives In The Implementation Of Local Government, Nomoi Law Review, Volume 1, Issue 1, May 2020, p. 93.

7 Aprilia Restuning Tunggal, Ilmu Hubungan internasional, (Yogyakarta: Graha Ilmu, 2013), p. 23.

${ }^{8}$ The objectives of the ASEAN form listed in the Bangkok Unity Annex, and also see the Ministry of Trade of the Republic of Indonesia "Towards the ASEAN Economic Community 2015), http://www.slideshare.net/ivaniedestila-bukumenuju-asean-Economic-community 2015, accessed on July 28, 2015.
}

nations of Southeast Asia that is prosperous and peaceful,

2. Enhancing regional peace and stability by respecting justice and law order in relations between countries in the Asean region and complying with the principles of the Charter of the United Nations.

3. Promote active cooperation and mutual assistance in matters of mutual interest in the fields of economy, social, engineering, science and administration,

4. Providing mutual assistance in the form of training and research facilities in the fields of education, profession, engineering and administration,

5. Cooperate effectively to increase the use of agriculture and industry, expand trade and study international commodity issues, improve transportation and communication facilities and improve the standard of living of their people,

6. Advancing the study of Southeast Asia,

7. Maintain close and useful cooperation with various international and regional organizations which have similar goals and to explore all possibilities for close cooperation among themselves.

After the formation of ASEAN and AFTA cooperative relations, the current issue is that Indonesia is already in the Asean Economic 
Community or MEA for short, of course together with 9 (nine) other ASEAN countries, namely Malaysia, Singapore, Thailand, Berunai Darussalam, Vieatnam, Laos, Myammar and Cambodia.

MEA is a form of ASEAN economic integration in the sense of a system of free trade between countries of Asean, that Indonesia and the 9 (nine) members of Asean countries Others have agreed agreement Masyara kat Asean Economic (MEA) and have been enacted at the end of December 2015 and, then at least provides the aim to increase Asean competitiveness and attract foreign investment that can rival those of China and India. ${ }^{9}$

International cooperation or relations is a very important element in the implementation of foreign policy and policy, including in the fields of economy, trade and education. Through this cooperation or international relations, Indonesia can actually take advantage of opportunities to support and carry out national development in realizing the MEA as an integrated region. It's just that integration within the European Union is at a higher level because it has integrated monetary policy using separate currencies, and frees traffic

\footnotetext{
9 Ibnu Hajar Damanik, Peran dan Tantangan Pendidikan Dalam Mengembangkan Sistem Pembelajaran menghadapi MEA, makalah disampaikan pada seminar internasional pada tanggal 18 April 2015 di Perguruan Assyafi'iyah Medan.
}

between citizens without having to use passports and having a central bank. S ecara MEA technical achievement using mechanisms and initiatives that have been established by ASEAN during this time that is reinforced by the institutional strengthening cooperation within ASEAN $^{10}$ included in education.

The ASEAN Economic Community can also be used as a training ground to compete freely with fellow ASEAN workers so as to make the workforce more productive and competitive, this is the forerunner and valuable capital in entering the MEA era, how universities, especially private universities, give birth to resources. human resources (lecturers) who are ready and competitive in entering the MEA era .

\section{The role of lecturers in the Asean Economic Community (MEA)}

Role, in other words " role" is a series of regular behavior and direct involvement of a person in determining the attitude of participating in advancing something. When viewed in a large Indonesian dictionary the definition of role is something that is part of the

10 Edy Suandi Hamid, Peran PTS Dalam Meningkatkan Kualitas SDM Menyongsong Generasi Emas Indonesia 2045, dan pentingnya soft Skill Bagi Para Lulusan Perguruan Tinggi, disampaikan alam kuliah umum stadium general UMN Al Washliyah pada tanggal 21 Oktober 2014. 
leadership, especially in the event of an event.

Dose n, the word "lecturer" can only be found and discussed in tertiary institutions, both public and private. When viewed from the aspect of academic and student development, all lecturers in the university environment certainly have a very important and very strategic role. Lecturers are professional staff who determine what is best for students in all matters that are still related to campuses and colleges in a professional and fair manner in placing and assessing things. In connection with the role of lecturers, there are also factors or causes for this role that can affect a person's role that comes from within oneself, groups, in organizations, the environment and the external environment. The role of lecturers in quality assurance and quality of higher education in this research is defined as the behavior or actions expected of a lecturer, in terms of implementing learning, research and community service tasks, including in promoting the campus to attract students to higher education, especially higher education. .

Lecturers are professional educators and scientists with the main task of transforming, developing and expanding science, technology, and arts through research education and community service. ${ }^{11}$ in other words, lecturers are one of the most important components in improving the quality and quality of education. Lecturers are also human resource academic persons, which are the main capital with great potential in increasing the progress of higher education. Therefore, lecturers play a very important role in improving the progress of higher education in the world of international competition in the era of the Asean Economic Community. In the Law of the Republic of Indonesia Number 20 of 2003 concerning the National Education System to be precise in article 35 paragraph 3 , it is stated that achieving the quality of education standards is not only determined by elements of educational staff including lecturers, but also how the higher education is managed based on content standards. , processes, competency of graduates, facilities and infrastructure, management, financing, and educational assessments that can be carried out by a body of standardization, assurance and quality control of education.

In addition, lecturers also have a position as professional staff at the higher education level who are appointed in accordance with statutory regulations and proven by having functional positions and educator

11 Law No. 14 of 2005 on Teachers Dosen, Article 1 Point 2. 
certificates that function to increase the dignity and role of lecturers as agents of learning, development of science, technology, and arts. , as well as serving the community which functions to improve the quality of national education.

In article 6 of Law no. 14 of 2005 concerning Teachers and Lecturers, it is explained that the position of lecturers as professional staff aims to implement the national education system and realize the goals of national education, namely the development of the potential of students to become human beings who believe and have devotion to God Almighty, noble, healthy, knowledgeable. , capable, creative, independent as well as being a democratic and responsible citizen.

Based on these definitions and meanings, the role of lecturers in realizing human resources who are skilled and ready to compete in relation to the Asean Economic Community can be interpreted as participating in directly participating in advancing universities to face international competition to determine competency-ready attitudes, for example, for example, what is the actual role lecturers in carrying out lectures properly and correctly. Lecturers need to identify the abilities that students are expected to achieve as well as their relevance in relation to the needs of the world of work they will face after graduating and obtaining a bachelor's degree in accordance with their respective fields. The ability of lecturers to explain and apply lecture material as teaching material to students is the first strategically important benchmark in applying the principles of relevance in education.

The role of the lecturer is not only as a teacher but also as a researcher and disseminator of the information contained in the Tri D harma of Higher Education. ${ }^{12}$ This means that lecturers' achievements are also determined by the number of papers presented in seminars, writing articles and publications in accredited scientific journals, international journals, reputable international journals, scopu s indexed international journals, weighty book writing. Lecturers also have to think logically, critically, master the principles and research methods so that they can apply them properly and efficiently. Thus the lecturers are always responsive to scientific, technological and social developments in society.

In addition, the duties and responsibilities of lecturers are to develop scientific attitudes through

${ }^{12}$ See Government Regulation No. 60 of 1999 on Higher Education, that the duties and responsibilities of lecturers have been mandated in the Tri Dharma of Higher Education which includes education and teaching, scientific research and publications, and community service activities. 
instilling curiosity, both for oneself and for others, because curiosity is the basis for a person to grow and develop intellectually by always looking for the truth.

\section{Lecturer Readiness in the Era of the Asean Economic Community}

\section{Readiness through the Design and Implementation of the Tri Dharma of Higher Education}

In line with the current development of higher education, with the availability of quality and quality Indonesian education that is relevant to the needs of national development, thus contributing to increasing the nation's competitiveness will certainly be achieved through education / teaching, research and community service.

The main task of a lecturer is to conduct teaching, research and community service who are members of the Tri Dharma of Higher Education, the three of which cannot be separated from one another. This means that teaching, research and community service must be in line, because it is a principle that is always held by every university in Indonesia, both public and private.

In essence, the Tri Dharma of Higher Education is not only carried out by lecturers, but students must also play a role in implementing the Tri Dhama of Higher Education together and it must be realized that all students are aware of the importance of the Tri

Dhama of Higher Education.

How does a lecturer design and carry out teaching, research, community service through the Tri Dharma Perguruan Tinggi, so that it goes well in accordance with the vision, mission and goals of the college, then all academics in the college environment must understand the contents of the Tri Dharma of Higher Education, as follows described in detail:

\section{Implementation of Teaching / Lectures}

When a lecturer will provide material in class (teaching), before teaching, of course, he already has thorough preparation, both physical, mental and material that will be conveyed to students. Preparation of lecturers in teaching can be done in various ways ranging from those that are very simple, simple, unique, and modern, for example understanding literature related to the material to be taught and developed with developments with the latest science by preparing teaching materials that are easily absorbed by students as well as preparing learning scenarios in class.

In addition, it is very important to carry out the learning process, so the elements that must be completed are "students, lecturers, room / class, curriculum / material" which will be delivered in class. In formulating the 
objectives of a course that is taught by a lecturer and given responsibility by the institution which is determined through the decisions given by the leadership to the lecturer, the lecturer must be able to formulate general and specific instructional goals according to the predetermined subjects. Lecturers need to identify the abilities that are expected to be achieved by students at the end of lectures.

The ability of the lecturer to formulate and explain instructional objectives as a whole and explain to students is the first strategic point of applying the principle of relevance in education, for example in the implementation of lectures in class, a lecturer must be able to do so that students are interested, the class atmosphere is more lively, students are not bored. , the learning process in class runs well, the lecturer must have a strategy, for example a lecturer brings students directly, makes learning media, invites experts who are experts, and so on.

In education and teaching, as long as students are in college, these students will gain various knowledge and insights in accordance with their chosen fields.

\section{Research Implementation}

One of the lecturers' activities in Tri Dharma Perguruan Tinggi is research. In relation to the principle of relevance, research that is relevant to the subject being taught and involving students should be more appreciated. Furthermore, the lecturer writes the lecture material completely and systematically, so that it is easier for students to learn and understand it.

Why do you have to research? Every lecturer who does research certainly has goals and objectives. In general, the goals and objectives of the academic community's research activities in higher education are as follows: ${ }^{13}$

a. Research aims at institutional development, which is carried out through research training for college lecturers, enrichment of teaching materials such as student learning processes and the development of a scientific atmosphere of academic culture.

b. Innovation research and science and technology development carried out through research for university lecturers in all schemes.

c. Research to solve national and regional problems is carried out through university collaboration with various agencies, both government, private and industry.

Based on the research objectives, it can be understood that if a lecturer conducts research, of course there will be many scientific insights and new findings obtained to develop

13 Lihat Panduan Pelaksanaan Peningkatan Sumber Daya Peneliti Perguruan Tinggi Dalam Pelatihan Penyusunan Proposal, UMN Al Washliyah, 2012, p. 1. 
the material to be taught when the teaching and learning process in the classroom.

Therefore, realizing the importance of the role of research in per higher education, in this case the Director General of Higher Education needs to encourage the development of regional and national innovation systems that can provide answers to various regional, national and global problems. In accordance with its capacity and based on national interests, the Directorate General of Higher Education develops national centers of excellence by utilizing existing expertise in various universities with a particular focus, both on the basis of sectors, commodities, and national strategic issues by involving scientific disciplines.

In this regard, the government through the Directorate of Higher Education also provides funding support for research which is explicitly stated in that law $^{14}$ " "Higher education institutions receive operational assistance from state universities (BOPTN) in which at least $30 \%$ (thirty percent) is allocated for research activities".

\section{Service Implementation}

Apart from teaching and research, community service is also the

14 Lihat dalam Undang-Undang No. 12 Tahun 2012 Tentang Pendidikan Tinggi tepatnya Pasal 89. third point of the Tri Dharma of Higher Education which is always the task of lecturers that must be fulfilled. We must understand this community service in the context of the application of science and technology that has been developed in tertiary institutions, especially the various results of research. So community service is a series of activities in the context of higher education contributions to society that are concrete and the benefits can be immediately felt in a relatively short time. This community service activity can be carried out with individual initiatives and groups of members of the academic community in the university environment with the support of higher education, with the hope that this community service activity provides feedback from the community to the university, as well as from the college itself to society which can then be used as material for further development of science and technology.

\section{To preparation Lecturer in Scientific Publications}

After conducting research, the results of the research or writing a writing, it is mandatory for lecturers to publish these writings, because lecturers as scientists have the task of developing a branch of science or technology through scientific reasoning and research and disseminating it. When choosing a 
profession as a lecturer either individually or in groups, a lecturer is obliged to write textbooks, textbooks, which are published as a source of learning and for the development of academic culture and the civilization of the academic community in all universities.

Not only that, the publication of lecturers' scientific works with the main task is to carry out the Tri Dharma of Higher Education, meaning that scientific publications can be carried out by all lecturers. Even though in reality there are many obstacles and obstacles in carrying out lecturers' scientific publications, where writing an idea into a writing is not a very easy thing to be made into a scientific work, it is certain that a lecturer needs very mature preparations in implementing it.

Scientific work is the result of research or thought that is published and written systematically in accordance with scientific and scientific principles, usually written in journals as places of publication, whether national journals, accredited national journals, international journals, reputable international journals. In each journal that we will choose, there are applicable provisions (both national journals, accredited national journals, international journals, reputable international journals), in other words the higher the quality of the journals to be selected, the more quality requirements will be required, and will be faced with to increasingly fierce competition.

Apart from being an obligation to carry out a scientific publication, this scientific work is also the main requirement for occupying certain academic levels, for example expert assistant, lecturer, head lecturer, up to the professorship level. For more details on the types of scientific publications required by each lecturer based on their respective academic levels, the following table can be observed: ${ }^{15}$

Table 1 :

Types of Scientific Publications based on Academic Position

\begin{tabular}{|l|c|c|c|}
\hline \multicolumn{1}{|c|}{$\begin{array}{c}\text { Academic } \\
\text { Position }\end{array}$} & $\begin{array}{c}\text { National } \\
\text { Journal }\end{array}$ & $\begin{array}{c}\text { Accredited } \\
\text { National } \\
\text { Journal }\end{array}$ & $\begin{array}{r}\text { Inter } \\
\text { Jo }\end{array}$ \\
\hline $\begin{array}{l}\text { Expert } \\
\text { Assistant }\end{array}$ & $\mathrm{w}$ & $\mathrm{s}$ & \\
\hline Lector & $\mathrm{w}$ & $\mathrm{s}$ & \\
\hline $\begin{array}{l}\text { Associate } \\
\text { Professor / } \\
\text { Masters }\end{array}$ & $\mathrm{s}$ & $\mathrm{s}$ & \\
\hline $\begin{array}{l}\text { Associate } \\
\text { Professor / } \\
\text { Doctor }\end{array}$ & $\mathrm{s}$ & $\mathrm{w}$ & \\
\hline Professor & $\mathrm{s}$ & $\mathrm{s}$ & \\
\hline
\end{tabular}

Note: Sumber Dikti, developed by the author

15 Dikti, Pedoman Operasional Penilaian Kenaikan Pangkat Jabatan Fungsional Dosen, dikyi, 2014. 
Note: $\mathrm{W}=$ mandatory, $\mathrm{S}=$ recommended .

Based on the table, it can be understood that for the promotion of a lecturer in all academic positions ( Expert Assistant, Lecturer, Head Lecturer, both Masters and Diploma, Professor) demands a journal, the higher the position we have, the greater the demand for quality and quality. the quality of scientific publications that we will publish.

For this reason, it is very important about the readiness of lecturers to carry out scientific publications. There are several efforts to improve lecturer performance through scientific publications to revitalize the function of higher education, including developing science and technology by increasing research benefits, including research funding.

To support the implementation of good publications, the Indonesian government is highly committed to improving the quality and quantity of higher education academic publications by providing financial assistance through research and community service.

\section{Readiness through Sotf skills and hard skills}

The words "Sotfskill and
Hard skills" cannot be separated,
because these two words are closely
related. Sotf skills are skills and life

skills, both for individuals, in groups, and in the community, including motivation, character, behavior and attitudes. Meanwhile, hard skills are technical skills that always practice and learn a lot.

Basically, the notion of Sotf skills is the ability that is inherent in a person / every human being that is formless and non- existent and cannot be seen in its form, but can be maximally developed and needed in the world of work as a complement to abilities and accompanied by hard skills.

To guarantee compliancewith these standards, an expectant step is required so that territorial regulation formulated by the competent educate in implementing the standards of the definition of legislation. Because the rule of law (in this setting the guideline of detailing of enactment) as it were indirectly provides rules, the guideline of law isn't alwaysposited in therule oflaw, then it gets to betroublesome to implementit within therun the show of law. ${ }^{16}$

As a lecturer in the world of education (higher education), it is inseparable from soft skills and hard

16 Eka N.A.M. Sihombing, Eddy Purnama, Budiman Ginting, Faisal Akbar Nasution, The Regional Regulation Concerning Management Of Zakat Viewed From The Principles Of Formulation Of Legislation, International Journal of Advanced Science and Technology, Vol. 29, No. 6, (2020). 
skills, because lecturers in this case must communicate well to their students appropriately and accurately and can be accepted and digested easily by others. In the world of education, lecturers are not only required to have soft skills, but lecturers must also increase graduates who are soft skills -based. If this is achieved properly, the needs of users of tertiary education graduates in the world of work with high productivity orientation will be fulfilled, so that of course what is the focus of the Asean economic community can be achieved properly.

Higher education is one of the spearheads in the development of national resources, all education implementers, especially lecturers, have a good perception of soft skills too, so that the policies that will be implemented by the lecturers themselves provide important motivation in improving student soft skills which are then applied in everyday life. In the future, softskills must to include in the law about education.

\section{Readiness of Lecturers in Ethics and Morals}

Basically, the emphasis in all activities as a lecturer is the attitude and behavior in carrying out duties and functions as a professional lecturer in their field, so that individuals who respect each other and work together for the common interest are developed. Moral and ethical values that are formulated in a standard code of ethics for a profession are none other than providing a path, guidelines, benchmarks and references for making decisions about what actions to take in certain situations and conditions, so that they can provide good service in accordance with profession and expertise respectively. When a lecturer does something, the important thing is to always be careful with the scope of ethics that is always wise in everything.

Ethical behavior is an important factor in the success and success that will be achieved because ethics is something personal that directs our own lives. Most of us, including lecturers, leaders, managers and others think we are among those who always have ethics. Whether the behavior we do is relevant to ethics as a profession that we each have, in this case is a lecturer. To be able to behave with good ethics, all of this needs to have a variety of knowledge, experience and full awareness of ourselves wherever we are.

As a lecturer who is always within the scope of the university, both public and private without exception, it is usually regulated in the ethics and manners of the lecturers. The formulation of lecturers' ethics and manners is aimed at forming an image of a lecturer who can be used as an example in entering a modern and professional society because a lecturer 
is a community figure and the academic community should have intellectual integrity and be open to change, especially in terms of progress in quality and quality of education in particular. at University. If all lecturers always have a good attitude and behavior as a member of the scientific community, they are honest, passionate, virtuous, responsible and avoiding indecent acts is in a lecturer. Then the ideals of higher education will be realized in accordance with the vision and mission of a college. For example, from the Pancasila aspect, that in the context of Indonesianness in fact the codification of ethical values already exists, namely taking shelter in "Pancasila" which is an Indonesian ideology where the values in it as well as the spirit contained in it are the essence of all the teachings of belief, the spirit of great spirituality. Therefore, the ethical and moral experience in Pancasila in this context is very important. Based on these ethics and morals, the existence of the Indonesian nation, especially those who work as lecturers, is a determinant of whether the nation is good or bad. So there will never be a moral crisis that hits our nation, including lecturers, if we practice Pancasila values.

\section{CONCLUSION}

Based on the analysis and discussion above, it can be concluded that lecturers have a very important role as Human Resources to improve the quality and quality of Higher Education in giving birth to a national generation ready to compete in the era of international competition in the Asean Economic Community (MEA). The role of lecturers in this case is also the duty and responsibility of written lecturers and has been mandated in the Tri Dharma of Higher Education which includes its role as an element in implementing education and teaching, research and scientific publications, as well as community service activities. Furthermore, another role is also to find out scientific attitudes through a sense of curiosity to search for the truth and the truth is applied in the tri Dharma of Higher Education.

As a suggestion, lecturers should always be ready to carry out their duties as a lecturer profession at any time, and it is better if the government in this case should also take responsibility for improving the performance of lecturers. The government must directly monitor lecturers in providing funding sponsorships, so that the lecturers continue their studies to improve the quality and quality of themselves as lecturers, so that they will become professional lecturers, especially in the Mea era. 
REFERENCES

Damanik, Ibnu Hajar, Peran dan Tantangan Pendidikan Dalam Mengembangkan Sistem Pembelajaran menghadapi MEA, makalah disampaikan pada seminar internasional pada tanggal 18 April 2015 di Perguruan Assyafi'iyah Medan

Dikti, Pedoman Operasional Penilaian Kenaikan Pangkat Jabatan Fungsional Dosen, dikti, 2014.

Hadita, Cynthia., Regional Autonomy Political Politics Of Regional Liability Reports To Regional Representatives In The Implementation Of Local Government, Nomoi Law Review, Volume 1, Issue 1, May 2020.

Hamid, Edy Suandi, Peran PTS Dalam Meningkatkan Kualitas SDM Menyongsong Generasi Emas Indonesia 2045, dan pentingnya soft Skill Bagi Para Lulusan Perguruan Tinggi, disampaikan alam kuliah umum stadium general UMN Al Washliyah pada tanggal 21 Oktober 2014.

http://temukanpengertian.blogspot.com /2013/09/pengertian-

persaingan.htmlhttp://temukanp engertian.blogspot.com/2013/0 9/pengertian-persaingan.html, diakses pada tanggal 6 Agustus 2015 http://www.slideshare.net/ivaniedestila -buku-menuju-aseanEconomic-community 2015, dan diakses pada tanggal 28 juli 2015

http://www.slideshare.net/ivaniedestila -buku-menuju-aseanEconomic-community 2015, dan diakses pada tanggal 28 juli 2015

Ibrahim, Johnny, Teori \& Metodologi Penelitian Hukum Normatif, Malang: Bayumedia, 2005.

Marzuki, Peter Mahmud. Penelitian Hukum, Jakarta: Kencana, 2005.

Panduan Pelaksanaan Peningkatan Sumber Daya Peneliti Perguruan Tinggi Dalam Pelatihan Penyusunan Proposal, UMN Al Washliyah, 2012.

Sihombing, Eka N.A.M., Eddy Purnama, Budiman Ginting, Faisal Akbar Nasution, The Regional Regulation Concerning Management Of Zakat Viewed From The Principles Of Formulation Of Legislation, International Journal of Advanced Science and Technology, Vol. 29, No. 6, (2020).

Sunggono, Bambang, Metode penelitian hukum (Suatu Pengantar), Jakarta: PT. Raja Grafindo Persada, 2001. 
Tunggal, Aprilia Restuning. Ilmu

Hubungan internasional, Ghara

Ilmu: Yokjakarta, 2013.

Undang-Undang No. 14 Tahun 2005

Tentang Guru Dosen.

Undang-Undang No. 12 Tahun 2012

Tentang Pendidikan Tinggi.

Peraturan Pemerintah No. 60 tahun 1999 tentang Perguruan Tinggi, bahwa tugas dan tanggung jawab dosen telah diamanatkan dalam Tri Dharma Perguruan Tinggi yang mencakup pendidikan dan pengajaran, penelitian dan publikasi ilmiah, dan kegiatan pengabdian kepada masyarakat. 